\title{
Resveratrol-enhanced wine
}

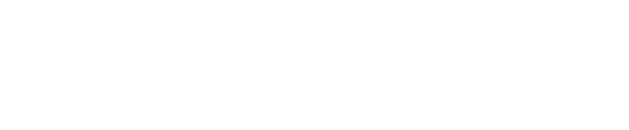

\section{Philip A Norrie}

General Medical Practitioner, Elanora Heights, NSW, Australia
Correspondence: Philip A Norrie 2/50 Kalang Road, Elanora Heights, NSW 2101, Australia

Tel +6I 299131088

Email winedoctor@bigpond.com
Man has been drinking wine for the last 9,000 years and the medical profession has been using it as a medicine for the past 5,000 years, making it man's oldest medicine. The greatest doctors and scientists of the past have sung its praises. Hippocrates (Greek physician and father of modern medicine, 460-370 BC) said "Wine is fit for man in a wonderful way provided it is taken with good sense by the sick as well as the healthy". Pliny the Elder (Roman scientist and historian, 23-79) said "In vino sanitas - in wine there is health" and Paracelsus (German physician and father of modern pharmacology, 1493-1541) said "Whether wine is a nourishment, medicine or poison is a matter of dosage", while Louis Pasteur (French scientist, 1822-1895) referred to wine as "The most healthful and hygienic of beverages". I refer to it as the thinking person's health drink.

Besides being man's oldest medicine, wine is also our best preventative medicine as shown by the Copenhagen City Study, ${ }^{1}$ which is the first ongoing longitudinal study to compare the death rates of abstainers and drinkers of beer, spirits, or wine. Previous studies had just compared teetotallers with alcohol drinkers of various rates of consumption of alcohol. The Copenhagen Study showed a $50 \%$ reduction in the death rate of wine drinkers compared to abstainers.

A new study from the Netherlands ${ }^{2}$ has reaffirmed wine's healthiest status. In the city of Zutphen, 1,400 males have been followed for the past 40 years and their life expectancy according to drinking preference recorded. All consumers of alcohol, in moderation, lived an average of $2 \frac{1}{2}$ years longer than abstainers, and wine drinkers, in moderation, lived an average of five years longer than abstainers. So wine, besides its alcohol content, has other constituents that make it the best alcoholic beverage. These other factors include salicylates, which act as anticoagulants or antithrombotics, and the large number of various antioxidants such as the polyphenols quercetin, epicatechin, and resveratrol.

The latest research paper to discuss the various antioxidants in wine and the major factors influencing their content in wine comes from the Czech Republic. ${ }^{3}$ Jaromir Lachman and colleagues from the Department of Chemistry, Faculty of Agrobiology, Food and Natural Resources at Prague's Czech University of Life Sciences showed that long-term intake of red wine increased antioxidant activity by $15 \%-20 \%$ compared to a control group.

So how can wine, our healthiest beverage, be made even healthier? After doing my $\mathrm{PhD}$ thesis on the history of wine as a medicine for the past 5,000 years, I turned my attention to this outcome. Increasing the alcohol content in table wine, which acts as an anticoagulant and raises the good cholesterol (high-density lipoprotein) in blood, is illegal unless you want to make a fortified wine. Increasing the salicylate content, to increase its anticoagulant and antithrombotic effects, would harm the taste of the wine. The logical components on 
which to focus in wine would be the antioxidants, especially the polyphenols. Of the polyphenols in wine, the most attractive one to increase would be resveratrol because not only is it a free radical scavenger and antioxidant but, and this is a big but, it is the only substance to stimulate SIRT1, the Sirtuin longevity gene that allows organisms to live longer by increasing the activity of the mitochondria in cells as shown by the work of Prof David Sinclair and his team at the AntiAging Laboratory at Harvard's School of Medicine. ${ }^{4}$ The only other way to stimulate $S I R T 1$ is by a caloric restriction of up to $30 \%$, something that is not a realistic option for our obesity-prone first-world society!

Resveratrol, after Prof Sinclair's research, has become the new "scientific superstar". Studies have shown that it helps reduce vascular disease, dementia, cancer, insulin resistance in diabetes as well as macular degeneration and so the list goes on. One of the latest studies from Xiaoying Zhang and colleagues at the Department of Pharmacology, South Dakota State University in the USA showed that resveratrol "significantly decreased the incidence and multiplicity of tumors in small intestine in rats and resveratrol significantly inhibited cell viability and cell proliferation in Caco-2 (human colic adenocarcinoma) cells."

Various methods have been tried to increase the resveratrol level in wine. In the vineyard researchers have sprayed the wines with water at vintage time - one of the roles resveratrol has in the grape skin is to protect it from fungal infection - and they have used ultraviolet radiation on the vines, all to no avail. Also unsuccessful were attempts to clone a high resveratrol content grape variety. In the winery, the late Prof Geoff Skurray, head of the Wine School at the University of Western Sydney, used a different enzyme to start the fermentation which liberated more resveratrol from the grape skin but also liberated more tannins and pigment, so that an undesirable tannin-rich, black wine would be produced. At the other end of the winemaking process, he used different fining and filtering techniques so that the increased resveratrol content would not be stripped out of the wine before bottling. Prof Skurray's modified winemaking techniques raised the resveratrol content by a maximum of $50 \%$.

My patented technique involves extracting resveratrol from the grape skins and adding Vitis vinifera grape-derived resveratrol back into the bulk wine blend at whichever concentration is desired at any time of the year prior to bottling so that it is independent of fermentation and can be made as strong as you like and is much, much higher than a $50 \%$ increase. Normal white wine has a resveratrol concentration of $1-2 \mathrm{mg} / \mathrm{L}$, while red wine's resveratrol concentration is $3-6 \mathrm{mg} / \mathrm{L}$. The added resveratrol does not change the wine's clarity, color, taste, or bouquet and I have had the resveratrol content in my wines analyzed as high as $155 \mathrm{mg} / \mathrm{L}$ one year after its addition, by Prof Skurray's laboratory. No longer do white wine drinkers have to feel they are drinking an inferior product because the new resveratrol-enhanced white wine has just as much resveratrol in it as the resveratrol-enhanced red wine! Resveratrol-enhanced wine now makes wine the latest nutraceutical of the 21st century and man's healthiest beverage.

My medical philosophy is based on preventative medicine: the concept that the best way to treat a disease is to not get it in the first place. The role of the medical profession and also now that of the winemaker is to help us die young, as late as possible. Winemakers are not purveyors of poison (as the antialcohol lobby would portray us) but are delayers of death through "oenotherapy".

The wine industry needs to change people's perception of wine from a beverage drunk occasionally for special events, such as birthdays, to one drunk daily (in moderation) for pleasure and health benefits. We also need to change the definition of health from the current narrow one of being disease-free, to a broader one of the ability to enjoy life physically, mentally, and environmentally.

\section{References}

1. Grønbaek M, Deis A, Sørensen TI, Becker U, Schnohr P, Jensen G. Mortality associated with moderate intake of wine, beer and spirits. BMJ. 1995;310:1165-1169.

2. Strepper MT, Ocke MC, Boshuizen HC, et al. Long-term wine consumption is related to cardiovascular mortality and life expectancy independently of moderate alcohol intake: the Zutphen Study. J Epidemiol Community Health. April 30, 2009. doi:10.1136/jech.2008.082198.

3. Lachman J, Šulc M, Faitová K, Pivec V. Major factors influencing antioxidant contents and antioxidant activity in grapes and vines. Int $J$ Wine Res. 2009;1:101-121.

4. Baur JA, Pearson KJ, Price NL, et al. Resveratrol improves health and survival of mice on a high-calorie diet. Nature. 2006;444:337-342.

5. Zhang X, Anderson J, Kaushik R, Dwivedi C. Effects of resveratrol, an important component of red wine, on intestinal cancer development. Int J Wine Res. 2009;1:147-153.
International Journal of Wine Research

\section{Publish your work in this journal}

The International Journal of Wine Research is an international, peer-reviewed open-access, online journal focusing on all scientific aspects of wine, including: vine growing; wine elaboration; human interaction with wine; and health aspects of wine. The journal provides an open access platform for the reporting

\section{Dovepress}

of evidence based studies on these topics. The manuscript management system is completely online and includes a very quick and fair peer-review system, which is all easy to use. Visit $\mathrm{http}: / / \mathrm{ww}$.dovepress.com/testimonials.php to read real quotes from some of our published authors. 